\title{
Museum practice in the developing of applied artists' professional competencies in the context of digitalization of education
}

\author{
Lubov Khoronko ${ }^{1}$ and Anna Mokina ${ }^{2 *}$ \\ ${ }^{1}$ Don State Technical University, 344003 Rostov on Don, Russia \\ ${ }^{2}$ Southern Federal University, 344007 Rostov on Don, Russia
}

\begin{abstract}
The article examines the modern approach in the pedagogical science of training future decorative and applied art artists, the search for new forms of practice, especially museum practice. The issue of forming future specialists' professional competencies is always acute, but today, in connection with the issues of the pandemic and the partial transition to distance learning, it has become particularly relevant and topical, including the field of art education. The authors are tasked to analyze the effectiveness of the discipline «Museum Practice» in a remote form, the development of professional competencies by bachelors. In the standard situation, this practice is partially conducted in the city museums where the university is located and also off-premise, by personal attendance, but in the 2019-2020 academic year, changes were made to the curriculum of the field of education «Decorative and Applied Arts and Folk Crafts» at the Southern Federal University, and the practice was held in an online form. The article considers the issue of remote dialogue between teacher-student-museum, identifies the positive and negative aspects of this form of communication for the development of professional competencies by future applied artists. The use of interactive, multimedia and visual technologies in the synthesis with independent work of the student gives a positive effect for the development of the necessary professional skills, even in a non-standard situation of practical training.
\end{abstract}

\section{Introduction}

The modern pedagogical system is equivalent to the competence-based approach. When forming effective professional competencies, each university models its own author's approaches and forms of their implementation. The whole "body" of the curriculum consists of a number of important elements that interact and enrich each other. The purpose of this interaction in the course of educational activities is the success and maximum implementation of specialists in future professional activities, the development of abilities, adaptation and preparation for real working conditions and the tasks of implementing their knowledge and skills in demand in the labor market. In modern society, a special role and significance is acquired by cultural heritage, immersion in the origins and history of all spheres of human

\footnotetext{
*Corresponding author: aymokina@list.ru
} 
development and culture [1]. In this regard, attention is drawn to museums as the main custodians and accumulators of historical values and cultural landmarks for modern society, especially young people. To effectively use the accumulated experience of museum collections and funds in theoretical, scientific, methodological, and educational creative areas of the young generation in educational activities, such concept as «museum pedagogy» has appeared. The forms of museum pedagogy can be guided tours, lectures, books, exhibitions, interactive lessons in museum spaces, etc. The educational and teasing activities of museums are actively introduced into the educational process from an early age, starting from preschool age, and are a continuous process within the framework of self-education and selfdevelopment of a mature person. Methods of museum pedagogy were interesting for: Sandra Kemp [2], Emanuela Bran, Bautu Bautu, Dorin Mircea Popovici [3], Maria Gregoriou [4], Shamsidar Ahmad, Mohamed Yusoff Abbasb, Wan Zaiyana Mohd Yusofab, Mohd. Zafrullah Mohd. Taib [5], Olga Susana Costa C. Araujo, Kathryn Hinsliff-Smith, Meire Cachioni [6], Fei Tan, Xin Gong, Mun C. Tsang [7].

The system of art education is impossible without the inclusion of museum pedagogy, for which the art history component is mandatory, especially in the formation of professional competencies. For the education of a successful creative personality, capable of solving highly artistic aesthetic tasks in professional activity, it is necessary to have an idea of the world's origins and traditions, of the trends in the art and culture development in modern conditions. The breadth and range of professional competencies set by universities individually, depending on the goals and objectives, in the training programs for future artists, architects, and designers have an impact on their further implementation in the profession and their demand in the labor market. In the context of increasing digitalization of the educational process, especially, actively implemented in the pandemic framework, it became necessary to make adjustments to the curricula, programs, forms and methods of teaching without losing quality.

Jingxian Wang, Dineke E. H. Tigelaar, Wilfried Admiraal [8], Øystein Gilje [9], Ekmel Çetin [10], Regina Schmid, Dominik Petko [11] discuss the issue of digitalization of the educational process in their works. In the field of culture and art, Zois Koukopoulos, Dimitrios Koukopoulos [12], Anne-Mette Nordvig, Anne Kristine Petersen, Helle Helsinghof, Birgit Brænder [13], Elena Neupokoeva, Nikolai Chapaev, Irina Suslova, Natalya Khokhlova, Alexander Sosnin [14] considered various aspects of working with students. During the COVID-19 pandemic Aneela Maqsood, Jaffar Abbas, Ghazala Rehman, Riaqa Mubeen [15], Mokina A. Yu., Khoronko L. Ya. [16] study innovative models and forms of conducting various types of practices, including in the system of higher art education. Today, the formation of highly professional qualities and the development of creative talents in the educational environment is formed by the heads of educational programs and teachers who implement the disciplines in practice, including conducting «Museum practice». But this discipline is practically not disclosed, especially in the current conditions of digitalization and the COVID-19 pandemic. According to Song M. J. [17] the architectural and artistic modern educational process is impossible without digital technologies.

\section{Materials and Methods}

The purpose of this research is to study the specifics of the use of digital technologies in the process of conducting «Museum practice» for applied artists in the framework of full distance learning in connection with the COVID-19 pandemic, to analyze the positive and negative aspects of pedagogical process in this form, taking into account art education 
specifics, to create an author's approach to the development of methodological forms of training in such conditions without loss for the quality of mastering the professional competencies of future specialists.

For this purpose, the following research methods were used: theoretical (analysis, synthesis, method of analogies, abstraction, generalization comparison [18]), including empirical (study of the experience of full-time forms of work, pedagogical observation,). The competence-based approach and the methodology of comparative pedagogy were chosen as the main methodologies.

Research base: The Department of Decorative and Applied Arts of the Southern Federal University is the base of experimental research of Museum Practice.

\section{Results}

Professional competencies of the future decorative and applied arts artist at the Southern Federal University are formed in the process of mastering most of the subjects of the module of professional branches of knowledge, as well as the module of practices developed by the head of the educational program of the field of study «Decorative and Applied Arts and Folk Crafts» (bachelor's degree), taking into account the world trends in the fine arts development. One of the important elements of the block «Practices», on an equal footing with other educational and industrial practices, is the discipline «Educational practice for obtaining primary professional skills, including primary skills and research activities. Museum», implemented in the 4th term. The main goal is to expand the knowledge gained in the theoretical classes «History of Art», «Theory and History of Decorative and Applied Art», «History of design, science and technology». As well as practical «Art design», «Propaedeutics» and others. Deep acquaintance with architectural monuments, masterpieces of painting, as well as with products of decorative and applied art and folk-art crafts of Russia, which serves as a stage in the developing of a bachelor's system of ideas about the essence of professional activity and a set of professional tasks in the field of developing and creating products of decorative and applied art and folk crafts.

According to the working program, museum practice consists of a number of full-time stages, which in a standard situation take place in museums in Rostov-on-Don, the Rostov region, as well as in the field part, students could visit major art museums and galleries, exhibition centers in Moscow, St. Petersburg, Riga, Prague and other cities, and student independent work, consisting in the acquired knowledge and information analysis, the study of fine art analogues.

The tasks for future artists were as follows:

- attendance at the expositions of museums, exhibition centers;

- listening to a series of introductory lectures and excursions;

- sketches of decorative and applied art items from museum collections;

- introduction to the scientific and practical basics of museum business;

- formation of the museum object passport;

- gathering, systematization and processing of information material.

The result of the museum practice is a research knowledge base, as well as practical sketches from real museum samples of fine art objects. All these facts become the basis for further student professional activity, both as a student (creation of original products of decorative and applied art in the subjects of «Art Design», «Conceptual Design», as well as final qualification work), and as an applied artist in the further professional field. In the course of Museum practice, future specialists in the field of art are immersed in the historical process of the origin and development of art and architecture, studying the technologies and 
techniques of creating certain works of art, understanding and distinguishing different genres, trends and styles. This type of activity contributes to the increase in visual information, immersion in the professional sphere, and the accumulation of analytical experience in working with museum collections and cultural heritage objects, which are necessary for future bachelors and masters of decorative and applied arts (see Fig. 1, 2).
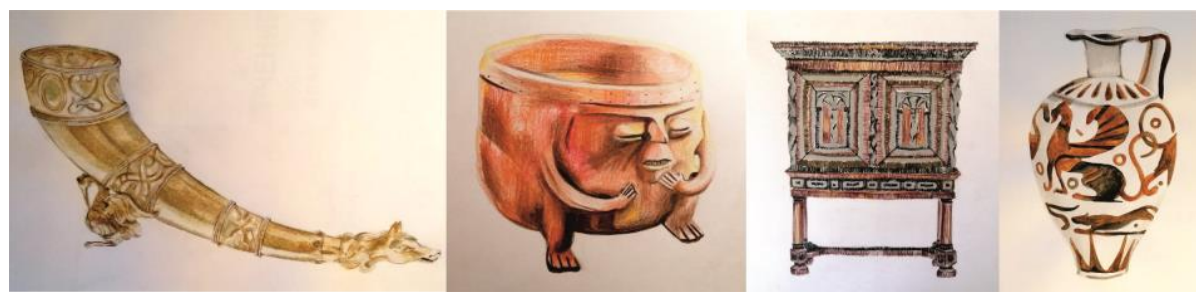

Fig. 1. The sketches by Flores Jaramillo Sandra Milena.
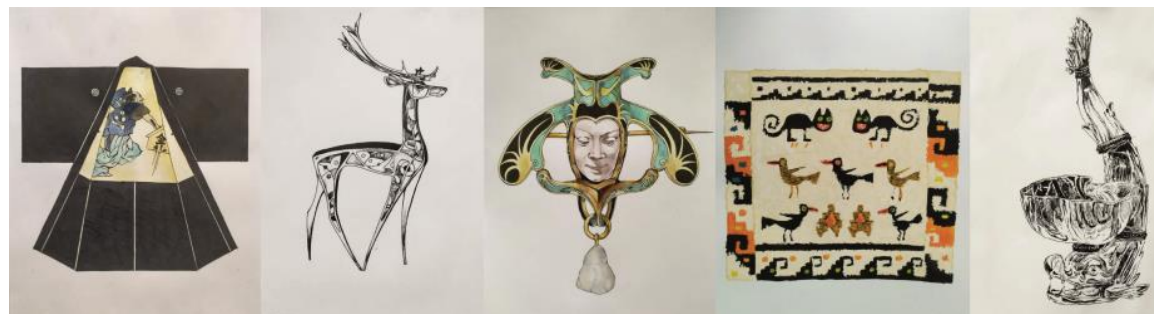

Fig. 2. The sketches by Kapusta Olga.

In the 2019-2020 academic year, the Department of Decorative and Applied Arts of the Southern Federal University made changes to the program of the course «Museum Practice» in connection with the situation of the COVID-19 pandemic. The form of conducting this course has become an exclusively remote form. During the internship, students had to visit at least 15 Russian and worldwide museums online, learn the history of the museum creation, the features of the collection, as well as explore the museum funds, focusing on decorative and applied art products.

In the modern variety of museums, the student chose the museum of interest according to his personal interests and his own desire, formed the content, volume and depth of information that he would like to receive, left a report on each collection, highlighting one particularly interesting object of the museum collection, making a sketch of it from the screen and making a passport of the museum object.

During this remote-analytical stage, the student is able to organize an exhibition, make annotations and explications of exhibits, conduct the exhibition tour, focusing on the features of the future exhibition project, and make a passport of the museum object with catalogue data if necessary. And also immerse yourself in the specifics of the restoration work, if it is carried out in the museum, taking into account the techniques, technologies and modern materials of decorative and applied art (Fig. 3). 


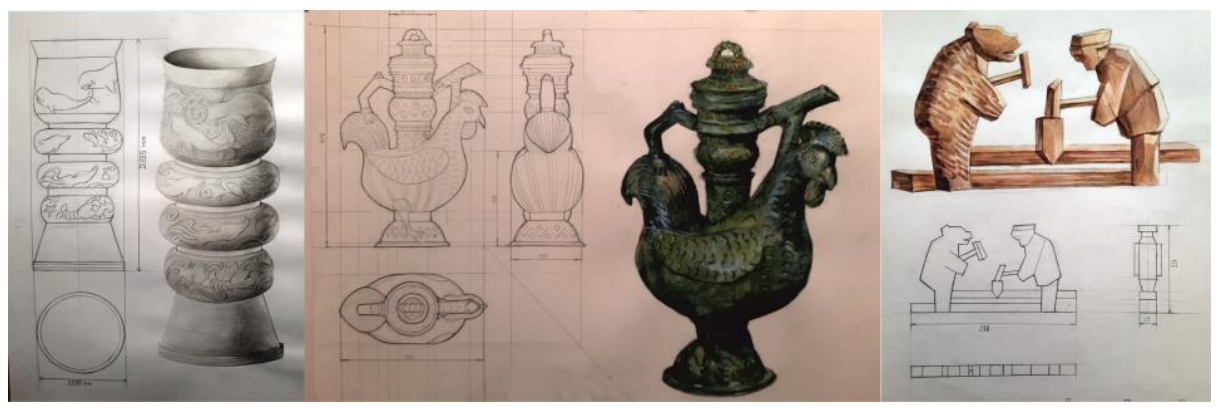

Fig. 3. The works of Kazmintsev E., Streltsov D., Statsenko P.

Students of the field of study «Decorative and Applied Arts and Folk Crafts» of the Southern Federal University in summer of 2020, while on distance learning, chose a wide range of worldwide museums, Russian and regional level, having studied museum funds, visited online excursions, listened to lecture material, examined decorative and applied art products in $3 \mathrm{~d}$ projections on museum websites and made a number of sketches and drawings of decorative and applied art products for museum object passports.

\section{Discussion}

One of the main tasks of the Department of Decorative and Applied Arts teachers is to ensure effective professional training of future graduates-artists using distance learning and non typical forms of art education in the course of museum practice within the pandemic framework. The effectiveness and productivity of such a learning process depended, among other things, on the students' position, their interest in the process of mastering professional skills, self-development and interest in the discipline in a remote form. The result of such a remote form of passing the museum practice was the preparation of a computer presentation in the web quest form with text forwarding of an individual task, discussion communication within the student group and the teacher.

The modern educational process in higher education requires rethinking and searching for new organizational and pedagogical forms of education in the context of digitalization, as well within the art education framework. In the process of studying museum practice, future applied artists gain experience in analytical and art history work, carrying out research and project activities, including using information and digital technologies. The introduction of such forms of training is effective in combination with traditional face-to-face visits to museums, but not in full replacement of such ones. This is due to the fact that students, having unlimited access to information through the official websites of art galleries or museums, viewing any expositions and works of art, do not sufficiently master information about the objects of fine and decorative art, about the techniques and materials of execution, about the exact color harmony through the screens of electronic devices, and also do not realize the scale of works, the subtleties of textures and textures of surfaces of museum collections objects. These subtleties can only be studied in person, visiting the expositions of galleries and museums. Also, the full-time form of the museum practice allows some students to plunge into the atmosphere of museum studies, the environment, the culture of creating museum collections and collections for the first time. Seeing a life-size work of fine or decorative art (miniature, easel and monumental work), for example, the Pazyryk carpet, in the State Hermitage Museum collection in St. Petersburg, which the student saw at a presentation during a lecture course or on a computer screen, understands how electronic illustration does not convey all the subtleties of color, textures of a centuries-old textile work, 
the subtleties of drawing, and most importantly, the future artist, in the face-to-face form, complements his impression and opinion about the work with an emotional component. Having the opportunity to examine the work in more detail, the student sees not only the color reproduction, but also the nature of the artist's brushstroke, transferring the most liked technique into his work. Familiarity with museum collections, funds and expositions, styles, folk art crafts, architecture offline not only expands the horizons of future applied artists, but also has a huge impact on the formation of his personality as a specialist and professional, ready to realize his creative potential in practice.

But it is also impossible to completely exclude the remote form as a form of conducting museum practice, since it is spatial. Time, as well as financial opportunities for full-time conducting of this discipline do not allow you to plunge into the museum world, for example, New York, Vancouver, Paris and other world capitals in the field of culture and art.

\section{Conclusions}

The synthesis of full-time museum practice and distance learning in the field of art education is the key to the success of solving a number of pedagogical goals and objectives set for both practice managers and students who acquire professional competencies in the learning process. The search for and implementation of new forms of learning within the framework of practices, including museum ones, guarantees the effectiveness and quality of building the educational process at the level of higher education.

Visual, analytical and art history information obtained in the course of face-to-face and distance classes in the course of museum practice strengthens not only theoretical knowledge, but also provides an opportunity to enrich professional skills in practice, to study expressive means and aspects of the development of world art and culture.

\section{References}

1. O. Fedotova, V.Latun, Mediterranean Journal of Social Sciences 6(4), 356-361 (2015) doi: 10.5901/mjss.2015.v6n4p356.

2. S. Kemp, Futures 94, 59-75 (2017) doi.org/10.1016/j.futures.2017.04.002.

3. E. Bran, B. Bautu, D. Popovici, Ubiquitous Knowledge Mixed Reality Museum 176, 2878-2885 (2020) doi.org/10.1016/j.procs.2020.09.266.

4. M. Gregoriou, Thinking Skills and Creativity 32, 51-65 doi.org/10.1016/j.tsc.2019.03.003.

5. A. Shamsidar, Yu. Mohamed, Z. Wan, et al., Procedia - Social and Behavioral Sciences 168, 156-170 (2015) doi.org/10.1016/j.sbspro.2014.10.221.

6. O. Araujo, K. Hinsliff-Smith, M. Cachioni, International Journal of Educational Research 102, (2020) doi.org/10.1016/j.ijer.2020.101591.

7. Fei Tan, Xin Gong, Mun C. Tsang, International Journal of Educational Research 106, (2021) doi.org/10.1016/j.ijer.2020.101729.

8. Jingxian Wang, E.H. Dineke, W. Admiraal, Computers \& Education 161, (2021) doi.org/10.1016/j.compedu.2020.104055.

9. G. Øystein, Culture and social interaction 21, 151-160 (2019) doi.org/10.1016/j.lcsi.2019.03.002

10. Ç. Ekmel, Thinking Skills and Creativity 39, (2021) doi.org/10.1016/j.tsc.2020.100760. 
11. R. Schmid, D. Petko, Computers \& Education 136, 75-86 (2019) doi.org/10.1016/j.compedu.2019.03.006.

12. Z. Koukopoulos, D. Koukopoulos, Applied Computing and Informatics 15(1), 19-26 (2019) doi.org/10.1016/j.aci.2017.09.004.

13. A. Nortvig, A. Petersen, H. Helsinghof, B. Brænder, Computers \& Education 159, (2020) doi.org/10.1016/j.compedu.2020.104020.

14. E. Neupokoeva, N. Chapaev, I. Suslova, N. Khokhlova, A. Sosnin, Thinking Skills and Creativity 39, 100753 (2021) doi.org/10.1016/j.tsc.2020.100753.

15. A. Maqsood, J. Abbas, G. Rehman, R. Mubeen, Current Research in Behavioral Sciences 2, (2021) doi.org/10.1016/j.crbeha.2020.100011.

16. L. Khoronko, A. Mokina, E3S Web of Conferences 210, (2020) doi.org/10.1051/e3sconf/202021022021.

17. M.J. Song, International Journal of Technology and Design Education 30(4), 687-707 (2020) doi: 10.1007/s10798-019-09524-6.

18. O. Fedotova, O. Chigisheva, International Perspectives on Education and Society 26, 57 82 (2015) doi: 10.1108/S1479-367920140000026003. 